\title{
Slower CCN growth kinetics of anthropogenic aerosol compared to biogenic aerosol observed at a rural site
}

\author{
N. C. Shantz ${ }^{1, *}$, R. Y.-W. Chang ${ }^{1}$, J. G. Slowik ${ }^{1}$, A. Vlasenko ${ }^{1, *}$, J. P. D. Abbatt ${ }^{1}$, and W. R. Leaitch ${ }^{2}$ \\ ${ }^{1}$ Department of Chemistry, University of Toronto, Toronto, Ontario, Canada \\ ${ }^{2}$ Science and Technology Branch, Environment Canada, Toronto, Ontario, Canada \\ *now at: Science and Technology Branch, Environment Canada, Toronto, Ontario, Canada
}

Received: 1 June 2009 - Published in Atmos. Chem. Phys. Discuss.: 23 June 2009

Revised: 27 November 2009 - Accepted: 16 December 2009 - Published: 15 January 2010

\begin{abstract}
Growth rates of water droplets were measured with a static diffusion cloud condensation chamber in MayJune 2007 at a rural field site in Southern Ontario, Canada, $70 \mathrm{~km}$ north of Toronto. The observations include periods when the winds were from the south and the site was impacted by anthropogenic air from the U.S. and Southern Ontario as well as during a 5-day period of northerly wind flow when the aerosol was dominated by biogenic sources. The growth of droplets on anthropogenic size-selected particles centred at $0.1 \mu \mathrm{m}$ diameter and composed of approximately $40 \%$ organic and $60 \%$ ammonium sulphate (AS) by mass, was delayed by on the order of $1 \mathrm{~s}$ compared to a pure AS aerosol. Simulations of the growth rate on monodisperse particles indicate that a lowering of the water mass accommodation coefficient from $\alpha_{c}=1$ to an average of $\alpha_{c}=0.04$ is needed (assuming an insoluble organic with hygroscopicity parameter, $\kappa_{\text {org }}$, of zero). Simulations of the initial growth rate on polydisperse anthropogenic particles agree best with observations for $\alpha_{c}=0.07$. In contrast, the growth rate of droplets on size-selected aerosol of biogenic character, consisting of $>80 \%$ organic, was similar to that of pure AS. Simulations of the predominantly biogenic polydisperse aerosol show agreement between the observations and simulations when $\kappa_{\text {org }}=0.2$ (with upper and lower limits of 0.5 and 0.07 , respectively) and $\alpha_{c}=1$. Inhibition of water uptake by the anthropogenic organic applied to an adiabatic cloud parcel model in the form of a constant low $\alpha_{c}$ increases the number of droplets in a cloud compared to pure AS. If the $\alpha_{c}$ is assumed to increase with increasing liquid water on the droplets, then the number of droplets decreases which could diminish the
\end{abstract}

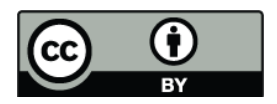

Correspondence to: N. C. Shantz (nicole.shantz@ec.gc.ca) indirect climate forcing effect. The slightly lower $\kappa_{\text {org }}$ in the biogenic case decreases the number of droplets in a cloud compared to pure AS.

\section{Introduction}

Aerosol particles affect the atmospheric radiation budget directly by scattering or absorbing radiation and indirectly by acting as cloud condensation nuclei (CCN). If the amount of cloud liquid water does not change with changes in $\mathrm{CCN}$, then an increase in the number of droplets leads to a decrease in the size of the droplets with increasing $\mathrm{CCN}$, thus influencing the radiative properties (Twomey, 1974) and lifetimes (Albrecht, 1989; Liou and Ou, 1989) of clouds. The extent of the cloud indirect effect of aerosol particles is highly uncertain (IPCC, 2007), and part of this uncertainty is understanding how the organic components contribute to the formation of cloud droplets. Carbonaceous material represents a significant fraction of atmospheric fine particle composition (Zhang et al., 2007). Mixtures of organic and inorganic components are complex and water uptake is difficult to characterize. The literature contains many examples of laboratory studies of the $\mathrm{CCN}$ behaviour of organic aerosol particles (e.g. Abbatt et al., 2005; Cruz and Pandis, 1997; Shantz et al., 2003; Shulman et al., 1996), but the focus is moving away from studying organics alone in the laboratory and moving towards studying the $\mathrm{CCN}$ character of ambient aerosols from different sources (i.e. mixtures that may contain organics) (e.g. Chang et al., 2007; Fountoukis et al., 2007; Gunthe et al., 2009; Ruehl et al., 2008, 2009; Shantz et al., 2008; Stroud et al., 2007; Wang et al., 2008).

Published by Copernicus Publications on behalf of the European Geosciences Union. 
Two significant sources of organic aerosols are the oxidation products of biogenic emissions (e.g. monoterpenes) and anthropogenic emissions (primary as well as oxidation products of anthropogenic volatile organic compounds, or VOCs). Laboratory proxies of organic biogenic aerosols have been found to be reasonably hygroscopic (e.g. Vesna et al., 2008; Wex et al., 2009) and CCN active in laboratory studies (e.g. Duplissy et al., 2008; Hartz et al., 2005; Jurányi et al., 2009; Prenni et al., 2007; VanReken et al., 2005). Wex et al. (2009) found that organic particles became more hygroscopic with increasingly diluted droplets. Duplissy et al. (2008) observed that the aerosol formed from $\alpha$-pinene oxidation became more $\mathrm{CCN}$ active over time when exposed to sunlight. VanReken et al. (2005) found the CCN activity to decrease as more oxidation products condensed on the aerosol in a dark experiment. Field observations of biogenic aerosols suggest that the organic fraction contributes to the CCN activity (Leaitch et al., 1999; Shantz et al., 2008). In contrast, several field studies focussed on anthropogenic emissions suggest that $\mathrm{CCN}$ closure is easily achieved if an insoluble organic is assumed, showing that the sulphate present in the aerosol dominated the CCN activity (Broekhuizen et al., 2006; Medina et al., 2007; Stroud et al., 2007). A number of studies suggest that the contribution of the organic components to the $\mathrm{CCN}$ activity increases when more of the organic component is assumed to be soluble (e.g. Chang et al., 2007; Ming and Russell, 2004).

The recent introduction of a single hygroscopicity parameter, $\kappa$, reduces the large number of physical and chemical parameters (e.g. molecular weight, density, ionic dissociation factor) and describes thermodynamical treatment of aerosolwater vapour equilibrium (Petters and Kreidenweis, 2007). For aerosols consisting of multiple components, the value of $\kappa_{\text {tot }}$ is given by a superposition: $\kappa_{\text {tot }}=\sum \varepsilon_{i} \kappa_{i}$, where $\varepsilon_{i}$ is the volume fraction and $i$ is the index representing the individual species (Petters and Kreidenweis, 2007). This parameter has been estimated for organic particles resulting from the oxidation of biogenic VOCs in smog chamber studies as 0.1 (Jurányi et al., 2009; Prenni et al., 2007) and 0.15 (Engelhart et al., 2008) and 0.02-0.05 in a biogenic field study (Shantz et al., 2008).

Leaitch et al. (1986) showed that growth kinetics can control droplet number concentrations, and Chuang et al. (1997) showed that neglecting kinetic limitations on the water uptake of cloud droplets can lead to overestimations in cloud radiative forcing calculations. The water vapour mass accommodation coefficient, $\alpha_{c}$, can have a strong effect on the condensation rate of water and remains an outstanding uncertainty in quantifying the indirect effect of aerosols on climate forcing. Literature values of $\alpha_{c}$ span 2 orders of magnitude, from 0.01 to 1 (e.g. Davidovits et al., 2004; Laaksonen et al., 2005; Marek and Straub, 2001; Mozurkewich, 1986; Voigtländer et al., 2007 and the references therein) and have been estimated to be as low as $10^{-5}$ for organic films on cloud droplet surfaces (Chuang, 2003). Ruehl et al. (2008) found that approximately $60 \%$ of the ambient $\mathrm{CCN}$ of urban, polluted regional and continental origins grew into cloud droplets at a similar rate as ammonium sulphate (AS). They observed a number of cases that had a lower $\alpha_{c}$ compared to $\mathrm{AS}$ at various sites.

In this paper, observations from a field study at Egbert, Ontario, Canada during the late spring of 2007 are used to contrast the CCN cloud droplet water uptake by aerosol particles containing organics from anthropogenic vs. biogenic sources. Water uptake growth kinetics were studied using a cloud droplet growth model that utilizes $\kappa$ to determine the hygroscopicity of the organic aerosol (Shantz et al., 2008). The rate of growth of aerosol particles containing anthropogenic organic components is found to be reduced.

\section{Experiment}

The Egbert 2007 field campaign took place May-June 2007 at a rural field site in Southern Ontario, Canada, $70 \mathrm{~km}$ north of Toronto (44.23 N, 79.78 W, see Fig. 1).

Much of the instrumentation used during the Egbert 2007 field campaign is described by Chan et al. (2009), Chang et al. (2009), Slowik et al. (2009) and Vlasenko et al. (2009). The focus of this work is on data from a static thermal diffusion chamber (University of Wyoming Model 100 CCN counter) used to study the initial growth rates of cloud droplets at a constant supersaturation (Shantz et al., 2003, 2008). The experimentally determined supersaturation used in this work is $S=0.35 \pm 0.05 \%$, found using monodisperse ammonium sulphate (AS) particles as discussed in Shantz et al. (2003, 2008). The polydisperse ambient aerosol was sampled directly into the CCN counter and a TSI 3022 Condensation Particle Counter (CPC) through a 3/8" OD stainless steel tube approximately $3 \mathrm{~m}$ in length with an intake point approximately $1 \mathrm{~m}$ above the roof of the building. In order to reduce the effect of dry particle size on the droplet growth rates, ambient aerosol particles were also size-selected with a TSI 3081 Long Differential Mobility Analyzer (DMA) during periods with measurable particle number concentrations. After size selection, the nearly monodisperse particle flow was split for measurement using the CPC and the CCN counter. Measured ambient growth rates from the $\mathrm{CCN}$ counter were compared to those of pure AS calibration aerosol at similar size and number concentration as the measured ambient aerosol, thus focussing on the effects of the chemical composition alone. The AS calibration aerosol was nebulized, dried, neutralized, and then size-selected with the DMA. The ambient size-selected aerosol was not dried prior to sampling but because particles would have tended to dry out as they travelled to the warmer temperatures inside the sampling building and the sheath flow in the DMA was dried, we believe the sampled particles would have very little water content. 
(a)

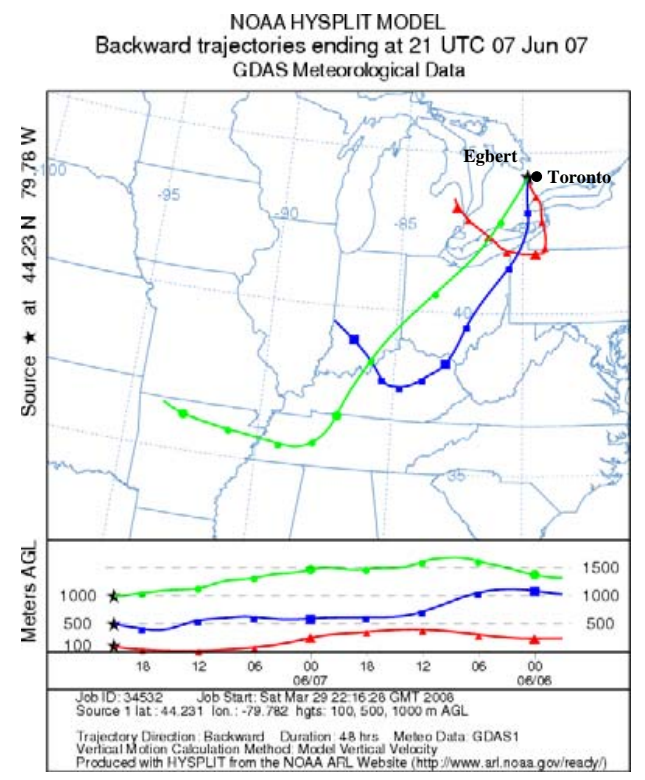

(b)

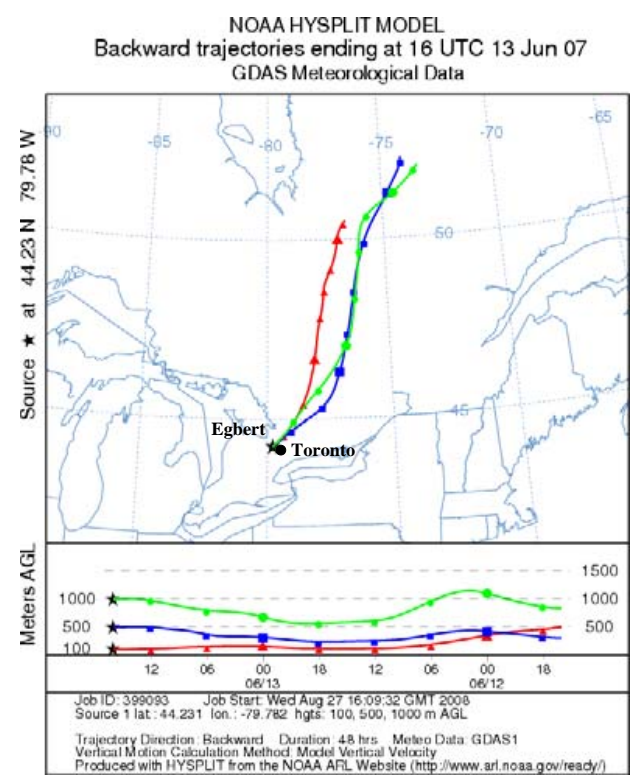

Fig. 1. Back trajectory analyses from the NOAA Air Resources Laboratory-HYSPLIT program for (a) an anthropogenically-influenced period (7 June) and (b) a biogenically-influenced period (13 June). Egbert, Ontario is the trajectory end point.

Ambient aerosol particle size distributions between $0.01 \mu \mathrm{m}$ and $0.4 \mu \mathrm{m}$ geometric diameter were determined with a Scanning Mobility Particle Sizer (SMPS) comprised of a TSI 3071 DMA and a TSI 3010 CPC (TSI Inc., St. Paul, MN, USA). The uncertainty in the number concentration is limited only by the uncertainty in the flow of the CPC which was estimated to be $10 \%$ (TSI Manual).

A time-of-flight (C-ToF) Aerosol Mass Spectrometer (AMS) (Aerodyne Research, Inc., Billerica, MA, USA) provides size-resolved, non-refractory chemical composition of aerosol particles measured in the range of approximately $0.04-0.7 \mu \mathrm{m}$ vacuum aerodynamic diameter $\left(D_{\mathrm{va}}\right)$, where for spherical particles $D_{\mathrm{va}}=\rho_{p} D_{\text {geo }}$, where $\rho_{p}$ is the particle density and $D_{\text {geo }}$ is the geometric diameter. Detailed descriptions of the AMS design, operation, quantification methods and calibration procedures are given elsewhere (Canagaratna et al., 2007; Drewnick et al., 2005; Jayne et al., 2000; Jimenez et al., 2003; Liu et al., 2007). The mass concentrations have been corrected for an average collection efficiency of 0.6 determined for this study (Slowik et al., 2009).

\section{Simulations}

There are two versions of a model used in this work; the difference between them is only with how the supersaturation is defined. Section 4.4 uses an adiabatic cloud parcel model (hereafter ACP model), described by Leaitch et al. (1986) and Shantz et al. (2003), where the rate of cooling of the air parcel plus the rate of water uptake are used to calculate the supersaturation. Sections 4.2 and 4.3 use a modified version of the parcel model that simulates droplet growth within the $\mathrm{CCN}$ counter (hereafter $\mathrm{CCNc}$ model) by applying a transient and then constant supersaturation environment to the particles (Shantz et al., 2003, 2008).

Some assumptions made in all simulations are as follows: a thermal accommodation coefficient of unity, spherical particles that are internally mixed and the compounds present in the particles/droplets do not chemically react with each other. The simulations are initiated with lognormal particle size distributions based on observations. The simulations incorporate the use of the hygroscopicity parameter, $\kappa$, introduced by Petters and Kreidenweis (2007), to evaluate the water uptake of ambient particles containing organics but this $\kappa$ does not incorporate time varying dissolution (Petters and Kreidenweis, 2008). Organic parameters that affect water uptake, such as molecular weight and density, vary greatly in the atmosphere and are largely unknown and thus the use of $\kappa$ groups them all into one quantity. Generally, with this $\kappa$-model, the surface tension of water is used ( $72.15 \mathrm{dyne}^{-1}$ ) and it is assumed that $\kappa$ captures all the variation in an aerosol's CCN activity arising from chemical composition including any reductions in surface tension due to surface-active species (even though the surface tension is not explicitly defined in the $\kappa$ formulation). It was assumed that all measured inorganics from the AMS were modelled as AS, which has a $\kappa_{\mathrm{AS}}=0.61$ (Petters and Kreidenweis, 2007). Sensitivity tests to ammonium nitrate $\left(\kappa_{\mathrm{AN}}=0.67\right)$ show very little difference from the AS simulations. To investigate the observations, we use 2 adjustable parameters for matching the simulations to the observed growth curves, $\kappa_{\text {org }}$ and $\alpha_{c}$. 


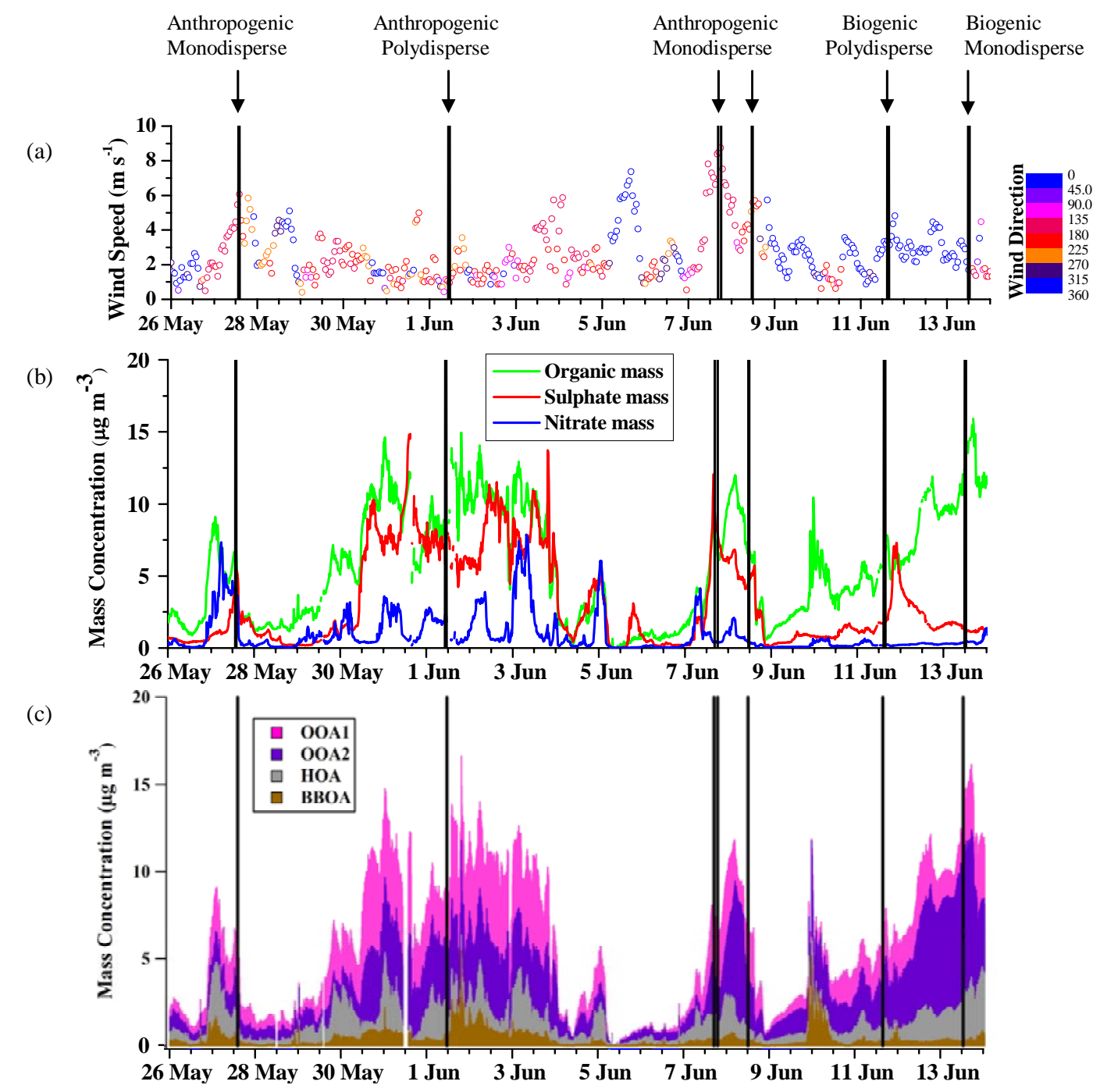

Fig. 2. Time Series from Egbert 2007 of (a) wind speed, colour-coded to wind direction (reds=south winds, blues=north winds), (b) organic, sulphate and nitrate mass concentrations from the C-ToF AMS and (c) stacked PMF factors for the organic mass concentration from the C-ToF AMS (details on the PMF factors in Slowik et al. (2009) and Chang et al. (2009)). Indicated in black lines are the case study periods discussed in this paper. Dates/times are in EDT, local time (LT).

These parameters are independent in terms of the formulation used here, but in reality there may be some connection between the two. Various organic $\kappa_{\text {org }}$ values are tested in Sect. 4. For pure AS simulations, we assume a mass accommodation coefficient of $\alpha_{c}=1$ (Davidovits et al., 2004; Laaksonen et al., 2005; Mozurkewich, 1986; Voigtländer et al., 2007). For ambient aerosols containing organics, a variety of $\alpha_{c}$ values are tested in Sect. 4.

\section{Results and discussion}

\subsection{Time series overview}

Figure 2 shows a time series of wind speed and direction (Fig. 2a, dates/times are in local time, LT, Eastern Daylight Savings Time, EDT), and the particulate mass concentrations from the AMS (Fig. 2b). In Fig. 2c, the organic component is represented as the time series of four factors obtained by positive matrix factorization (PMF) analysis of the AMS mass spectra, described in detail in Slowik et al. (2009) and briefly summarized below. PMF analysis represents the AMS organic mass spectral time series as a linear combination of factor mass spectra and their corresponding time series. The analysis yielded four distinct factors 
(1) hydrocarbon-like organic aerosol (HOA), correlated with tracers for primary anthropogenic emissions; (2) biomassburning organic aerosol (BBOA), a slightly oxygenated factor with a mass spectrum similar to levoglucosan; and ( 3 and 4) two oxygenated organic aerosol factors, denoted OOA-1 and OOA-2. Here OOA-1 is the more oxygenated factor and correlates with tracers for long-range transport (e.g. particulate sulfate), while OOA-2 correlates with VOCs indicative of more recent oxidation (e.g. methacrolein and methyl vinyl ketone, oxidation products with atmospheric lifetimes of approximately half a day). As discussed elsewhere (the revised version of Slowik et al., 2009), the OOA-1 and OOA-2 factor mass spectra are similar to those of low-volatility OOA (LV-OOA) and semivolatile OOA (SV-OOA), respectively (Jimenez et al., 2009). Because tracer correlations suggest that the Egbert time series are primarily driven by factors other than volatility, the more general OOA-1/OOA-2 terminology is used here.

Air reaching the site from the south is typically influenced by anthropogenic sources from the U.S. and the highly populated Southern Ontario region (e.g. 7 June in Fig. 1a). During times of southerly winds (Fig. 2a, red shades), higher mass concentrations of organic and sulphate were measured (e.g. 30 May-4 June and 7-9 June in Fig. 2b).

When winds were from the north (Fig. 2a, blue shades), the aerosol mass concentrations were usually lower (Fig. 2b). An exception to this was near the end of the study, 9-13 June, when north winds persisted (with few anthropogenic sources) and air reaching the site had travelled over a large fetch of mixed forests (e.g. 13 June in Fig. 1b). Figure 2b shows the organic mass concentration increased steadily over this time period. The gas-phase and aerosol signatures as well as regional modelling indicates that the origin of most of the organic aerosol during this period was from the oxidation of biogenic precursors (Slowik et al., 2009).

\subsection{CCN growth kinetics of monodisperse aerosol}

Examples of droplet growth curves of size-selected ambient particles compared to AS particles at $S=0.35 \%$ are shown in Figs. 3a and 4a. The CCN counter raw detector voltage depends on the size distribution and the chemical composition of the dry aerosol particles and the size of the growing droplets. Traditionally with this $\mathrm{CCN}$ counter, the maximum voltage (as observed around 10 s in Figs. 3a and 4a) is used to determine the $\mathrm{CCN}$ number concentration based on a calibration with an inorganic aerosol such as ammonium sulphate. Due to uncertainties associated with the relationship between voltage and CCN counts, we focus only on the kinetics of droplet growth.

In this section, we eliminate the effects of the number concentration and the size of the dry particles by size-selecting a nearly monodisperse ambient aerosol and comparing it to an AS calibration aerosol at the same size and number concentration. By doing so, we are able to study the effects of the chemical composition without significant influence of the size distribution.

The data of Fig. 3 were collected during a period when the winds were from the southwest (Fig. 1a) and the aerosol had been transported over populated Southern Ontario and the Ohio valley. Figure 3a shows the growth curves of ambient anthropogenic aerosol (size-selected to a diameter of $0.1 \mu \mathrm{m}$ with a geometric standard deviation of $\sigma_{g}=1.1$ and an aerosol number concentration $\left(N_{a}\right)$ of $220.9 \pm 0.7 \mathrm{~cm}^{-3}$, where the error is $2 \times$ standard error) and AS calibration aerosol $\left(0.1 \mu \mathrm{m}, \sigma_{g}=1.1\right.$ and $\left.N_{a}=219.8 \pm 2.2 \mathrm{~cm}^{-3}\right)$. The AS calibration aerosol begins to accumulate water at approximately $2 \mathrm{~s}$ and grows through $8 \mathrm{~s}$. After $8 \mathrm{~s}$, the water droplets begin to fall from the detection region and the signal decreases. The maximum voltage for AS reaches a higher value than the ambient aerosol, suggesting more $\mathrm{CCN}$ activated in the AS case compared to the ambient. Comparing the initial growth of the ambient anthropogenic aerosol relative to the AS particles, it is clear that the anthropogenic aerosol is delayed in its initial growth compared to AS.

A droplet growth model that mimics the chamber supersaturation (the CCNc model, Sect. 3) was applied to investigate possible explanations for the delayed growth of the ambient aerosol. The model is initiated with nearly monodisperse particles with approximately $87 \%$ (by number concentration) of the dry particles centred at $0.1 \mu \mathrm{m}$ and $13 \%$ of the dry particles centred at $0.14 \mu \mathrm{m}$ (the doubly charged particle mode that exit the DMA). Figure $3 \mathrm{~b}$ shows the model results (cross section, right axis) limited to $5 \mathrm{~s}$ as well as the observed growth rates (voltage, left axis) for AS and ambient aerosols from Fig. 3a. Only the first $5 \mathrm{~s}$ are shown as the model does not include the droplet gravitational settling as the droplets grow larger. The left and right axes are scaled according to the AS calibration results (Shantz et al., 2008). For the pure AS simulation, we assume that the water mass accommodation coefficient, $\alpha_{c}$, is unity; the droplets formed on AS grow to $1.4 \mu \mathrm{m}$ diameter by $5 \mathrm{~s}$ into the simulation.

Figure $3 \mathrm{c}$ shows the AMS time-of-flight chemical composition measurements. The $D_{\text {va }}$ were converted to $D_{\text {geo }}$ by assuming spherical particles and using the following material densities: $\rho_{\mathrm{AS}}=1.77 \mathrm{~g} \mathrm{~cm}^{-3}$ (CRC, 2004) and $\rho_{\text {org }}=1.3 \mathrm{~g} \mathrm{~cm}^{-3}$ (Cross et al., 2007). The mass fractions of the ambient particles were estimated from the data shown in Fig. 3 c to be $62 \%$ AS and $38 \%$ organic at $D_{\text {geo }}=0.08-0.12$ $\mu \mathrm{m}$ with midpoint $D_{\mathrm{geo}}=0.1 \mu \mathrm{m}$; these mass fractions were used in all 7 June simulations shown in Fig. 3b, except the pure AS simulation.

If the organic present in the 7 June case was not contributing at all to the water uptake, and only the AS present in the aerosol is contributing to the water uptake, we would expect a delay relative to the pure AS growth rate, but is it as significant as what was observed in Fig. 3a? We perform a simulation assuming a mass accommodation coefficient of $\alpha_{c}=1$, a $\kappa_{\mathrm{AS}}$ of 0.61 (Petters and Kreidenweis, 2007) and a $\kappa_{\mathrm{org}}$ of 0 (i.e. the organic was assumed to not contribute to the ini- 

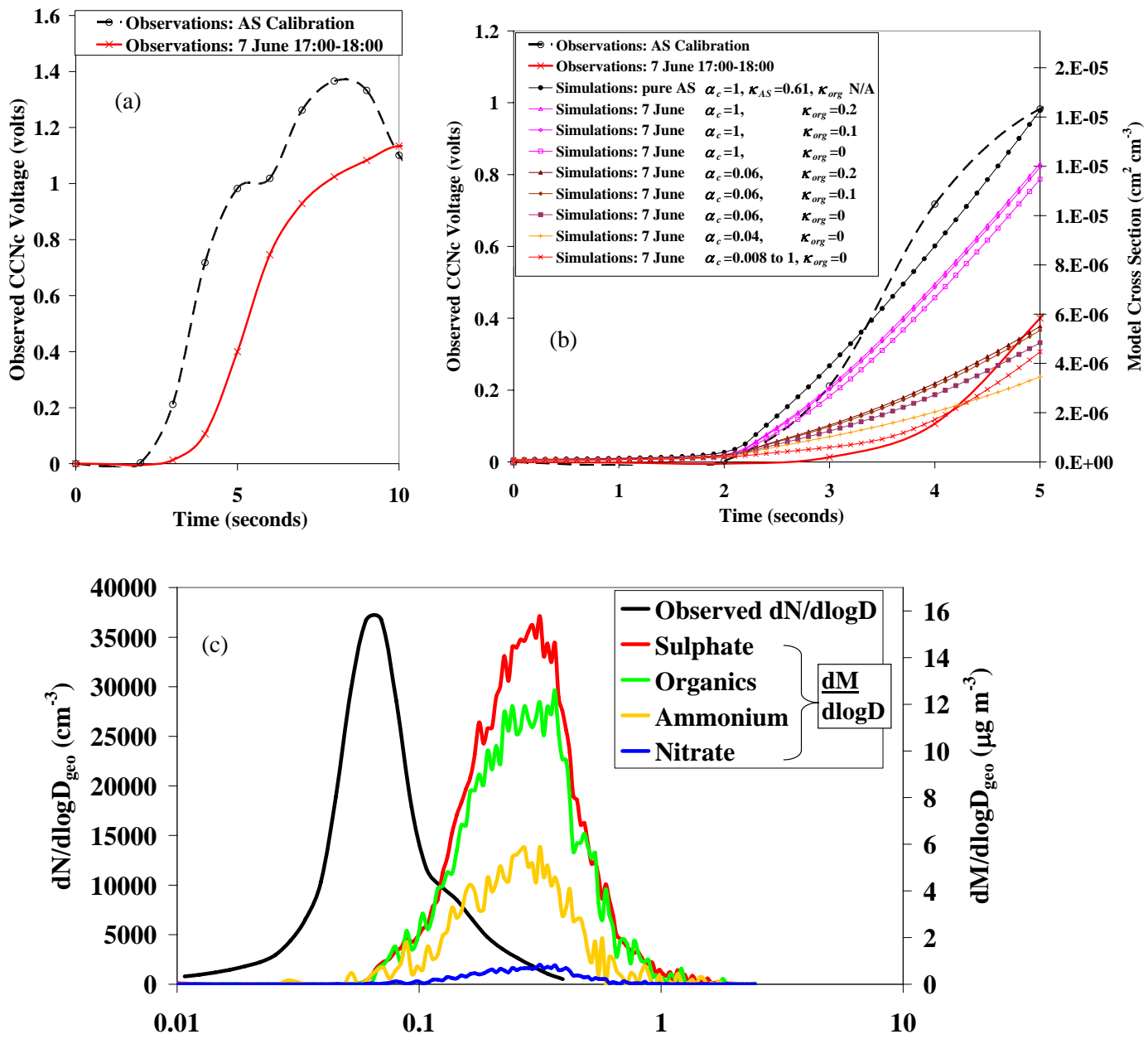

Geometric Diameter $(\mu \mathrm{m})$

Fig. 3. 7 June 2007, 17:00-18:00 LT anthropogenic case with south winds. (a) Observations of CCN counter droplet growth rates (shown as a voltage) on particles size-selected to $0.1 \mu \mathrm{m}$ diameter (dry) at $S=0.35 \%$ and number concentrations of $215-225 \mathrm{~cm}^{-3}$. The bottom axis is the sample time as the particles activate and grow into cloud droplets. (b) The observed growth rates from the CCN counter from (a) correspond to the left axis. The right axis shows the droplet cross-sectional area calculated in the simulations. The simulations assume $62 \% \mathrm{AS}\left(\kappa_{\mathrm{AS}}=0.61\right)$ and $38 \%$ organic $\left(\kappa_{\mathrm{org}}\right.$ varied $)$ mass fractions for a nearly monodisperse aerosol centred around $0.1 \mu \mathrm{m}$. This figure is constrained to $5 \mathrm{~s}$ because the model does not simulate the droplet gravitational settling. (c) Mass distributions from the AMS particle time-of-flight measurements (right axis) and number size distributions (left axis) from the SMPS. The bottom axis shows the geometric diameter (converted from $D_{\mathrm{va}}$ assuming a particle density $\rho=1.63 \mathrm{~g} \mathrm{~cm}^{-3}$, calculated assuming $\rho_{\mathrm{AS}}=1.77 \mathrm{~g} \mathrm{~cm}^{-3} \mathrm{and}_{\text {org }}=1.3 \mathrm{~g} \mathrm{~cm}^{-3}$ ).

tial water uptake). Although there was a slight delay in this simulation compared to the AS simulation, it is not nearly as significant as the observed delay. Since $\kappa_{\text {org }}=0$ is already underestimating the observed delay, increasing $\kappa_{\text {org }}$ will not help achieve agreement between the observations and simulations, as shown in Fig. 3b. Instead, lower values of $\alpha_{c}$ $(0.04-0.06)$ are necessary to produce the observed delays. These results suggest that the organic compounds present in the ambient aerosol inhibited initial water uptake by these $\mathrm{CCN}$. The possibility of an organic coating suppressing hygroscopicity was observed elsewhere (Johnson et al., 2005) where volatilization of a low solubility organic that may have coated the particles resulted in a clear increase in the water uptake. This kinetic inhibition was also observed in polluted air masses in continental USA (Ruehl et al., 2008, 2009). However, if there was an organic film present, it is possible that the organic film would break, would no longer impede water uptake and thus would grow readily (Feingold and Chuang, 2002). Increasing hygroscopicity with increased droplet dilution has been observed (Wex et al., 2009). In fact, if $\alpha_{c}$ increases with the accumulation of water on the particles, then it may explain the rise in the ambient growth curve after $4 \mathrm{~s}$. The effect of an increasing $\alpha_{c}$ with water uptake is also shown in Fig. 3b, with the best match to the observations simulated with an initial $\alpha_{c}=0.008$ and increasing $\alpha_{c}$ exponentially up to unity (determined by comparing simulations 
Table 1. Observations from the size-selected nearly monodisperse ambient aerosol of stronger anthropogenic influence. Simulations were used to determine $\alpha_{c}$ for the anthropogenic cases compared to AS calibration simulations (assuming $\alpha_{c}$ of unity). The organics in the simulations are assumed to have $\kappa_{\text {org }}$ of zero.

\begin{tabular}{lllllllll}
\hline $\begin{array}{l}\text { Date } \\
(\mathrm{dd} \text { mmm) }\end{array}$ & Time & $\begin{array}{l}D_{\text {geo }} \\
(\mu \mathrm{m})\end{array}$ & $\begin{array}{l}\text { Number } \\
\text { conc. } \\
\left(\mathrm{cm}^{-3}\right)\end{array}$ & $\begin{array}{l}\text { Organic } \\
\text { mass } \\
\text { fraction at } \\
D_{\text {geo }}\end{array}$ & $\begin{array}{l}\text { Inorganic } \\
\text { mass } \\
\text { fraction at } \\
D_{\text {geo }} *\end{array}$ & $\begin{array}{l}\text { Approx. } \\
\text { delay } \\
\text { time } \\
(\mathrm{s})\end{array}$ & $\begin{array}{l}\alpha_{c} \text { estimated } \\
\text { range }\end{array}$ & $\begin{array}{l}\alpha_{c} \text { midpoint } \\
\text { of estimated } \\
\text { range }\end{array}$ \\
\hline 27 May & $13: 33-14: 05$ & 0.12 & $95-105$ & 0.53 & 0.47 & 1 & $0.03-0.05$ & 0.04 \\
07 June & $16: 37-16: 42$ & 0.10 & $285-295$ & 0.40 & 0.60 & 1 & $0.04-0.07$ & 0.055 \\
07 June & $16: 44-16: 58$ & 0.10 & $265-275$ & 0.40 & 0.60 & 1.25 & $0.03-0.05$ & 0.04 \\
07 June & $17: 01-18: 00$ & 0.10 & $215-225$ & 0.38 & 0.62 & 1 & $0.04-0.06$ & 0.05 \\
07 June & $18: 00-18: 17$ & 0.10 & $205-215$ & 0.39 & 0.61 & 0.75 & $0.05-0.07$ & 0.06 \\
08 June & $11: 26-11: 46$ & 0.10 & $65-75$ & 0.48 & 0.52 & 1 & $0.01-0.03$ & 0.02 \\
\hline & & & & & & Average $\alpha_{c}$ & & 0.04 \\
\end{tabular}

* All observed inorganics are assumed to be ammonium sulphate with $\kappa_{\text {AS }}$ of 0.61

and observations) based on the liquid water content (LWC) of the droplets (in each size bin, $\alpha_{c}=0.008 \exp (5 \mathrm{e} 11 \mathrm{LWC})$ where LWC is in units of grams of $\mathrm{H}_{2} \mathrm{O} \mathrm{cm}^{-3}$ ). This simulation seems to capture the curvature of the observations the best, suggesting an organic film may have initially inhibited the water uptake but broke apart as the water accumulated on the droplet.

This analysis was performed for 6 anthropogenic cases when the aerosol was size-selected to $0.1 \mu \mathrm{m}$ observed on 3 different days during the field campaign and the results are summarized in Table 1. The delays in the initial growth rates of the $\mathrm{CCN}$ droplets were estimated by comparing the ambient growth rate with the corresponding AS calibration growth rate at the same size and number concentration. The $\alpha_{c}$ ranges from 0.01 to 0.07 and the mean $\alpha_{c}$ is 0.04 . This result may be consistent with Stroud et al. (2007) who found that $\alpha_{c}=0.07$ was needed to achieve closure in a case study of a pollution episode and with Fountoukis and Nenes (2005) who reported $\alpha_{c}=0.042$ as an optimal value. In the present case, a low $\kappa_{\text {org }}$ and a lower $\alpha_{c}$ or increasing $\alpha_{c}$ with increasing LWC best describes the droplet growth of the anthropogenic aerosol.

The water uptake growth rates of the aerosol measured during the biogenic period, when the air travelled from the northeast (Fig. 1b), sampled with the CCN counter is shown in Fig. 4a. The ambient biogenic aerosol was size-selected to a diameter of $0.12 \mu \mathrm{m}$ with $N_{a}=37.1 \pm 0.2 \mathrm{~cm}^{-3}$ (error is 2 $\times$ standard error) and the AS calibration aerosol at $0.12 \mu \mathrm{m}$ with $N_{a}=39.0 \pm 1.2 \mathrm{~cm}^{-3}$ and both with a variance of $\sigma_{g}=1.2$. The pure AS case is different from that shown in Fig. 3a because of the lower number concentration in the case shown in Fig. 4a. Figure $4 \mathrm{~b}$ shows this period was dominated by an organic aerosol. Growth of this biogenic aerosol is not delayed relative to the AS aerosol even though the majority of the aerosol is organic. Although our previous field studies have indicated a CCN-active biogenic aerosol (Leaitch et al., 1999; Shantz et al., 2008), the comparable CCN activity between the organic-dominated aerosol and the pure AS aerosol observed at Egbert was unexpected. In fact, if we apply a constant $\mathrm{CCN}$ number concentration calibration to the maximum voltages, more $\mathrm{CCN}$ are activated in the ambient biogenic case than the pure AS calibration aerosol. However, the aerosol numbers are relatively low in this case and the estimation of $\kappa_{\text {org }}$ from the comparison of the simulations and observations cannot be constrained. We evaluate possible $\kappa_{\text {org }}$ values for the biogenic case in Sect. 4.3.

\subsection{CCN growth kinetics of polydisperse aerosol}

We compare the anthropogenic and biogenic CCN abilities further using polydisperse data from different days at $S=0.35 \%$. Because we could not produce an AS calibration with the exact polydisperse ambient aerosol size distribution, we rely on the model described in Sect. 3 to study the effects of chemical composition on water uptake.

Figure 5a shows the droplet growth rates of the anthropogenic aerosol observed from the CCN counter for 1 June, as well as the CCNc model simulations. The error bars show the uncertainties that arise from errors in the calibrated supersaturation. The model size distribution assumption (based on the SMPS) was set up as shown in Fig. 5b. From the AMS chemical mass distribution (Fig. 5b), the growth rates were modelled assuming that modes 1 and 2 consist of $50 \%$ AS and $50 \%$ organic and mode 3 consists of $60 \%$ AS and $40 \%$ organic (mass fractions) with $\kappa_{\text {org }}=0$. The best match with the observations is for the assumption of $\alpha_{c}=0.07$ and $\alpha_{c}$ can be constrained within the supersaturation uncertainty to $\alpha_{c}=0.05-0.11$, which are at the upper end of the result for the size-selected anthropogenic aerosol (Sect. 4.2). 

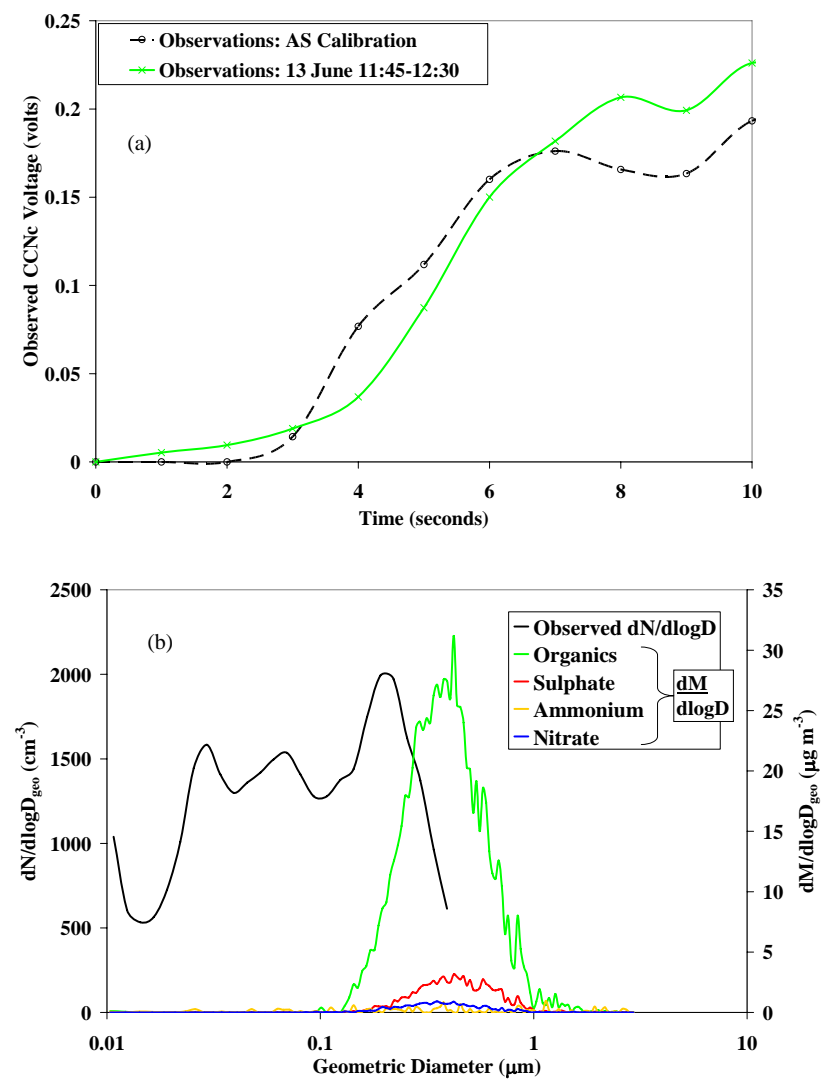

Fig. 4. 13 June 2007, 11:45-12:30 LT biogenic case with north winds. (a) Observations of $\mathrm{CCN}$ counter droplet growth rates on particles size-selected to $0.12 \mu \mathrm{m}$ diameter at $S=0.35 \%$ and number concentrations of $35-45 \mathrm{~cm}^{-3}$. (b) Mass distributions (11:00-12:00) from the AMS particle time-of-flight measurements and number size distributions from the SMPS (11:45-12:30). The bottom axis shows the geometric diameter (converted from $D_{\text {va }}$ assuming a particle density $=1.38 \mathrm{~g} \mathrm{~cm}^{-3}$, calculated assuming $\rho_{\mathrm{AS}}=1.77 \mathrm{~g} \mathrm{~cm}^{-3}$ and $\rho_{\mathrm{org}}=1.3 \mathrm{~g} \mathrm{~cm}^{-3}$ ).

Following the same procedure for a biogenic case (Fig. 6, with chemical composition assumptions that all 3 modes are $20 \%$ AS and $80 \%$ organic), we find that $\kappa_{\text {org }}=0.2(0.07$ in the first few seconds of growth) and $\alpha_{c}=1$ gives the best agreement between the model and the observed growth curves. The range $\kappa_{\text {org }}=0.07-0.5$ demonstrates that the values are within the supersaturation uncertainty. The biogenic organic contributes to the water uptake in this case as the levels of sulphate are relatively low. These polydisperse experiments corroborate the findings from Sect. 4.2, that the monodisperse biogenic case was $\mathrm{CCN}$ active.

For the above simulations, we had assumed a surface tension of water $\left(72\right.$ dynes $\left.\mathrm{cm}^{-1}\right)$. With the $\kappa$-model, a surface tension assumption is required but when determining the value of $\kappa_{\text {org }}$ the effects of all changes in the chemical composition on the initial water uptake of these particles are incorporated; this includes any change in surface tension rel- ative to the assumed value. We do not attempt to specify which component(s) are responsible for changes in the $\kappa$.

The AMS PMF analysis suggests that the anthropogenic organic aerosol has a higher OOA-1 fraction (the more oxygenated factor) than the biogenic aerosol (Fig. 2c); the latter aerosol perhaps consisted of freshly emitted, small and soluble organic compounds that activate readily. However, the overall oxygen to carbon ratio, which is proportional to the AMS $m / z$ 44/total organic (Aiken et al., 2008), is similar between the time periods discussed here (7 June 10:00-18:00: $\mathrm{m} / \mathrm{z}$ 44/total organic $=0.113 \pm 0.007,1$ June 10:26-11:05: $\mathrm{m} / \mathrm{z}$ $44 /$ total organic $=0.110 \pm 0.008$ and 11 June $14: 45-15: 35: \mathrm{m} / z$ $44 /$ total organic $=0.117 \pm 0.004)$. The fact that the anthropogenic aerosol with more OOA-1 exhibits characteristics that appear to slow down the rate of water uptake and that the biogenic aerosol with more OOA-2 (the less oxygenated factor) takes up water readily is counter to the more common concepts of organic CCN activation (Kanakidou et al., 2005) and it is not clear which compounds lead to this result. We suggest the possibilities that the more aged anthropogenic organic components may have a higher average molecular weight which would cause them to be less hygroscopic, and/or that the water uptake suppression may be due to organic films arising from the HOA coating of the aerosol, which would reduce the $\mathrm{CCN}$ activity. However, because we are comparing organic compounds from different sources and the individual types of organics measured in both of these cases are unknown, we can only speculate on the differences between the $\mathrm{CCN}$ activity of the anthropogenic and biogenic organic aerosols.

\subsection{Adiabatic cloud parcel model simulations}

The results from the previous sections were used in the ACP model (Sect. 3) to consider the impact of the initial water uptake delay on the number concentrations of cloud droplets. Table 2 shows the number of activated droplets $\left(N_{d}\right)$ above the maximum supersaturation in a cloud for updraft velocities of $20 \mathrm{~cm} \mathrm{~s}^{-1}$ and $100 \mathrm{~cm} \mathrm{~s}^{-1}$ and for aerosol number and chemical size distributions represented by the anthropogenic (7 June and 1 June) and biogenic (11 June) observations. All size distributions are scaled to $1500 \mathrm{~cm}^{-3}$ total number concentration for simpler comparison.

The biogenic simulation included $\kappa_{\mathrm{org}}=0.2$ and $\alpha_{c}=1$ (Sect. 4.3) as well as a base case of pure AS with the same size distribution. For these assumptions, the $N_{d}$ are 0.80 0.89 of the $N_{d}$ for pure AS due to a lower $\kappa_{\text {org }}(0.2)$ than $\kappa_{\mathrm{AS}}$ (0.61).

The anthropogenic 7 June simulation included $\kappa_{\text {org }}=0$ and $\alpha_{c}=0.04$ (the average value found in Sect. 4.2) and a varying $\alpha_{c}$ that increased with increasing LWC in each particle size bin. The anthropogenic 1 June simulation included $\kappa_{\text {org }}=0$ and $\alpha_{c}=0.07$ (from Sect. 4.3) and a varying $\alpha_{c}$. The base cases for each anthropogenic case were run with the same chemical size distributions but with $\alpha_{c}=1$ and then for a pure 

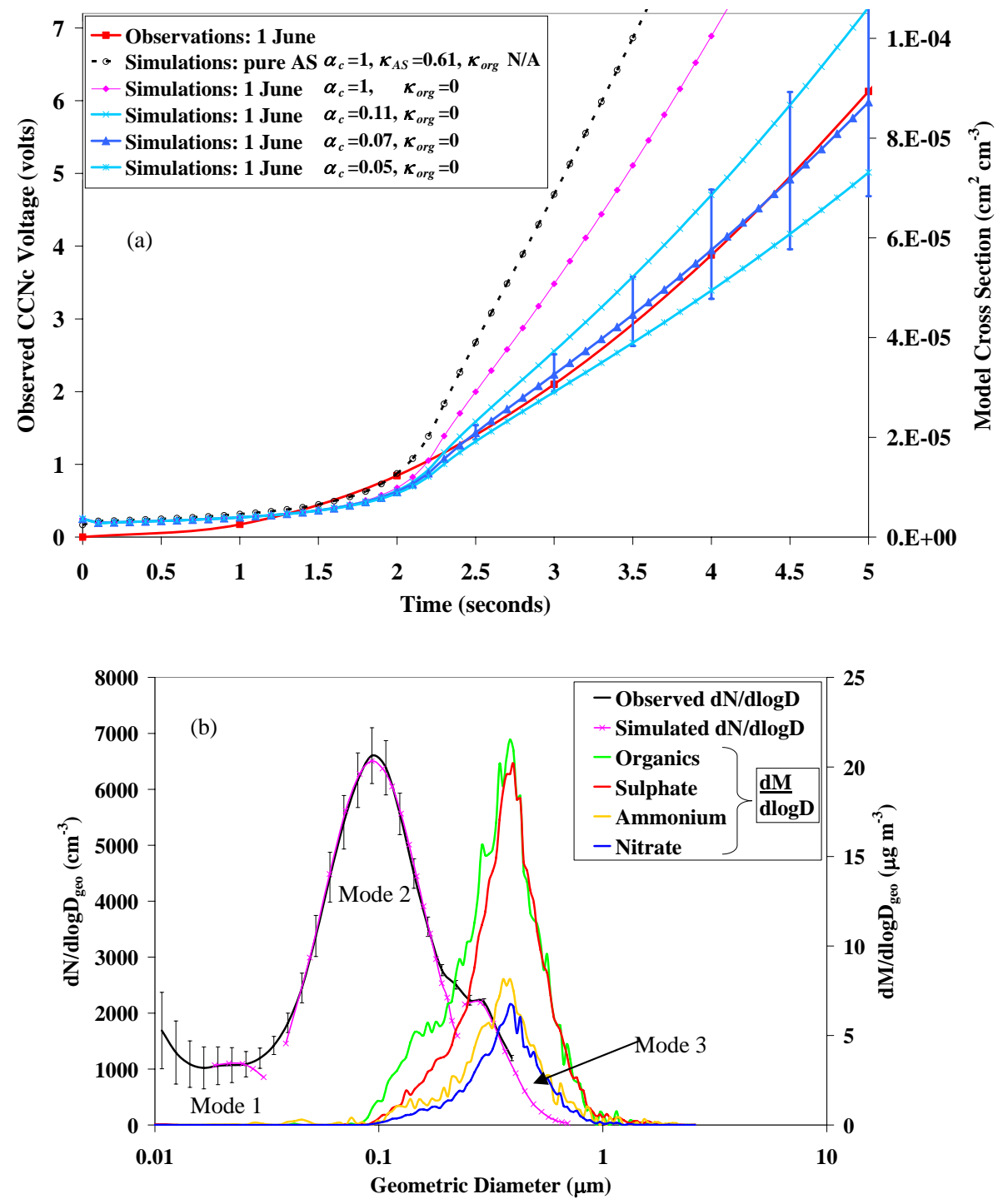

Fig. 5. 1 June 2007, 10:26-11:05 LT anthropogenic case with south winds. (a) Observations of CCN counter droplet growth rates for polydisperse ambient aerosol measured at $S=0.35 \%$. The red solid line is the observed growth rate from the CCN counter (left axis) and all other curves are the modelled growth rates shown as cross-sectional area (right axis). The error bars demonstrate simulations performed at $S= \pm 0.05 \%$ to reflect the error in the calibrated supersaturation. (b) Observed (from the SMPS measurements, shown in black, with error bars $=2 \times$ standard error) and modelled (pink) number size distribution (left axis) and observed mass distributions from the AMS particle time-of-flight measurements (right axis). The $D_{\mathrm{va}}$ have been converted to geometric diameter assuming a particle density=1.54 $\mathrm{g} \mathrm{cm}^{-3}$, calculated assuming $\rho_{\mathrm{AS}}=1.77 \mathrm{~g} \mathrm{~cm}^{-3}$ and $\rho_{\mathrm{org}}=1.3 \mathrm{~g} \mathrm{~cm}^{-3}$.

AS and $\alpha_{c}=1$. The delay observed for the anthropogenic 7 June case modelled with a constant low $\alpha_{c}$ leads to an $N_{d}$ that is 1.18-1.62 times higher than the case with the same chemical compositions but with $\alpha_{c}=1$ (Table 2). This lower $\alpha_{c}$ also results in an $N_{d}$ that is 1.04-1.29 times higher compared to that for the pure AS case $\left(\alpha_{c}=1\right)$. If we assume $\alpha_{c}$ increases with the accumulation of water on the particles, as discussed in Sect. 4.2, the $N_{d}$ decreases compared to the constant $\alpha_{c}$ simulations in the $100 \mathrm{~cm} \mathrm{~s}^{-1}$ simulation. In this case, the larger particles activate readily, increasing their $\alpha_{c}$ and depleting the excess water vapour so that the smaller sizes, for which the $\alpha_{c}$ remains lower, are unable to activate. Thus, depending on if and how $\alpha_{c}$ changes during the condensation process, the anthropogenic organic components may either enhance or diminish the indirect effect. A similar trend was observed in the anthropogenic 1 June simulations. Overall, these simulations suggest that the delay in the anthropogenic aerosol water uptake and the biogenic aerosol's lower $\kappa_{\text {org }}$ compared to $\kappa_{\mathrm{ASS}}$ may lead to slightly lower $N_{d}$ than pure AS. The exception to this is if the $\alpha_{c}$ remains low throughout the droplet growth process; a possibility that seems unlikely. 

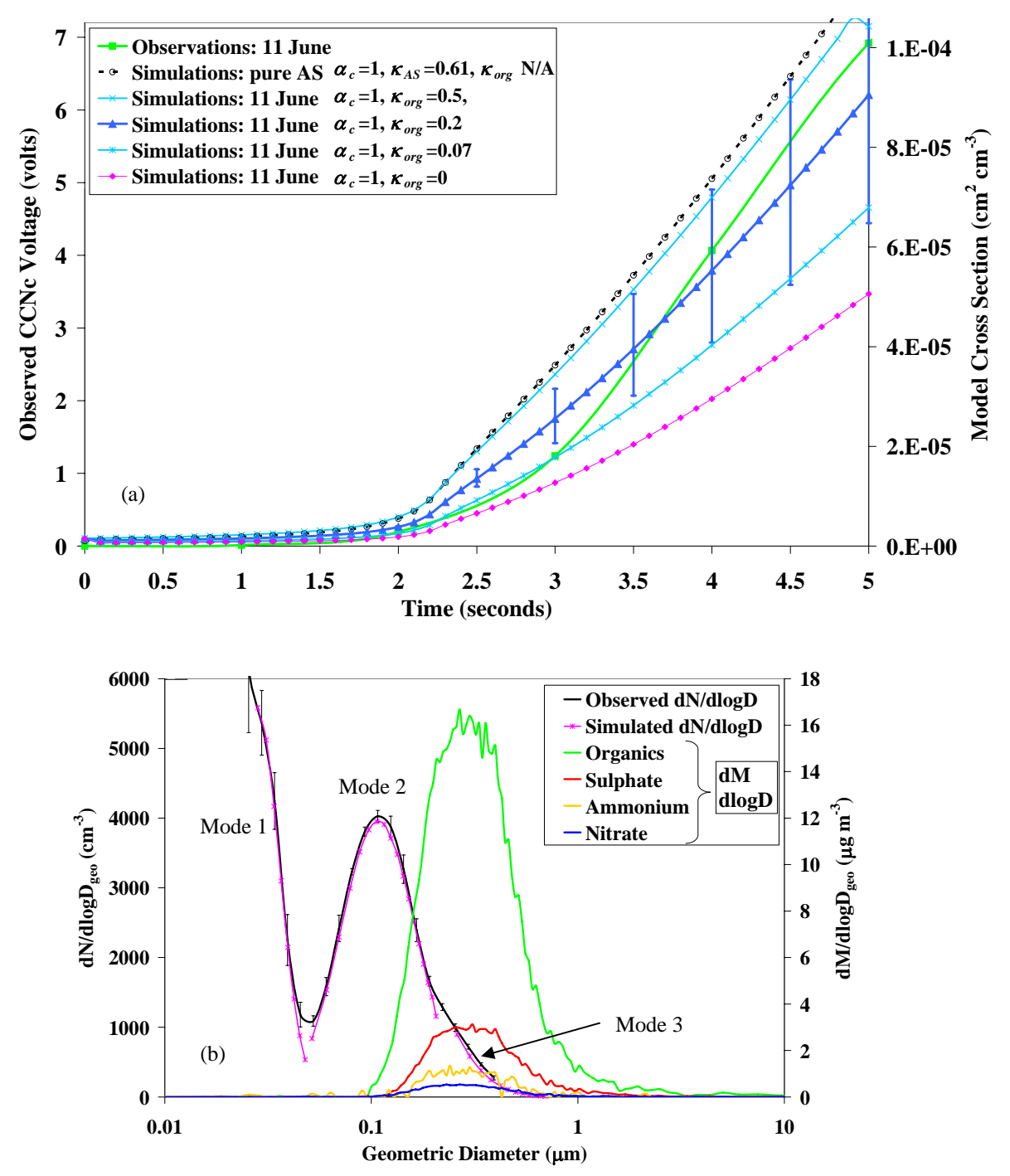

Fig. 6. 11 June 2007, 14:45-15:35 LT biogenic case with north winds. (a) Observations of CCN counter droplet growth rates for polydisperse ambient aerosol measured at $S=0.35 \%$. The green solid line is the observed growth rate from the CCN counter (left axis) and all other curves are modelled growth rates shown as cross-sectional area (right axis). (b) Observed (from the SMPS measurements, shown in black, with error bars $=2 \times$ standard error) and modelled (pink) number size distribution (left axis) and mass distributions from the AMS particle time-of-flight measurements (right axis). The $D_{\mathrm{va}}$ have been converted to geometric diameter assuming a particle density $=1.4 \mathrm{~g} \mathrm{~cm}{ }^{-3}, \mathrm{calculated} \mathrm{assuming}^{-3}$ $\rho_{\mathrm{AS}}=1.77 \mathrm{~g} \mathrm{~cm}^{-3}$ and $\rho_{\mathrm{org}}=1.3 \mathrm{~g} \mathrm{~cm}^{-3}$.

A second effect that shows up in the modelling is of some significance to the indirect effect. Hypothetically, if the updraft velocity is the same but one case has a reduced growth rate compared to the other, then the adiabatic cloud LWC has to be reduced. Even if $N_{d}$ increases, persistently low growth rates (i.e. $\alpha_{c}=0.04$ ) reduce the LWC compared to simulations with $\alpha_{c}=1$ (Table 2). At the lower updraft speed, the reduction in LWC for the variable $\alpha_{c}$ is about $0.02 \%$, whereas the reduction for the higher updraft is $0.24 \%$ (7 June) or $0.12 \%$ (1 June) compared to pure AS. This indicates that at least at cloud base and for higher updraft speeds, there can be insufficient time for the droplets to reach equilibrium when organic components from anthropogenic sources are present in the aerosol.

With a persistent smaller $\alpha_{c}$, the $N_{d}$ is higher because the cloud base supersaturation is increased. However, the effect of the higher $N_{d}$ may be offset by a reduction in LWC. In the more likely situation where the $\alpha_{c}$ starts relatively low and increases as the droplets increase in size, the change in the growth rates reduces the $N_{d}$ and LWC. 
Table 2. Simulations from the adiabatic cloud parcel model for anthropogenic and biogenic case studies assuming the surface tension of water. The total mass fractions, hygroscopicity parameters $(\kappa)$ and mass accommodation coefficients $\left(\alpha_{c}\right)$ are unitless. The number of droplets $\left(N_{d}\right)$ and liquid water content (LWC) found in these simulated clouds is determined well above the maximum supersaturation ( $80 \mathrm{~m}$ above cloud base) for 2 updraft velocities $(u), 20$ and $100 \mathrm{~cm} \mathrm{~s}^{-1}$. "Anth" is anthropogenic aerosol, "Biog" is biogenic aerosol and "AS" indicates simulations that were run using the ambient size distribution from the date indicated but with the composition as pure ammonium sulphate. All simulations are scaled to the same total number concentration of $1500 \mathrm{~cm}^{-3}$. Also, only particles $>0.05 \mu \mathrm{m}$ are simulated here.

\begin{tabular}{|c|c|c|c|c|c|c|c|c|c|c|}
\hline \multirow[t]{2}{*}{$\begin{array}{l}\text { Date } \\
\text { (dd mmm) }\end{array}$} & \multirow[t]{2}{*}{ Case } & \multicolumn{2}{|c|}{$\begin{array}{l}\text { Total Mass } \\
\text { Fraction }\end{array}$} & \multirow[t]{2}{*}{$\kappa_{\text {org }}$} & \multirow[t]{2}{*}{$\kappa_{\mathrm{AS}}$} & \multirow[t]{2}{*}{$\alpha_{c}$} & \multicolumn{2}{|c|}{$\begin{array}{c}\text { LWC } \\
\left(\mathrm{g} \mathrm{m}^{-3}\right)\end{array}$} & \multicolumn{2}{|c|}{$\begin{array}{c}N_{d} \\
\left(\mathrm{~cm}^{-3}\right)\end{array}$} \\
\hline & & Org. & Inorg. $^{\mathrm{a}}$ & & & & $\begin{array}{l}u=20 \\
\mathrm{~cm} \mathrm{~s}^{-1}\end{array}$ & $\begin{array}{l}u=100 \\
\mathrm{~cm} \mathrm{~s}^{-1}\end{array}$ & $\begin{array}{l}u=20 \\
\mathrm{~cm} \mathrm{~s}^{-1}\end{array}$ & $\begin{array}{l}u=100 \\
\mathrm{~cm} \mathrm{~s}^{-1}\end{array}$ \\
\hline 7 June & Anth & 0.37 & 0.63 & 0 & 0.61 & 0.04 & 0.17946 & 0.17507 & 280 & 991 \\
\hline 7 June & Anth & 0.37 & 0.63 & 0 & 0.61 & $0.008-1^{b}$ & 0.17965 & 0.17525 & 237 & 564 \\
\hline 7 June & Anth & 0.37 & 0.63 & 0 & 0.61 & 1 & 0.17965 & 0.17539 & 237 & 610 \\
\hline 7 June & AS & 0 & 1 & N/A & 0.61 & 1 & 0.17969 & 0.17568 & 268 & 766 \\
\hline 1 June & Anth & 0.40 & 0.60 & 0 & 0.61 & 0.07 & 0.17966 & 0.17544 & 325 & 926 \\
\hline 1 June & Anth & 0.40 & 0.60 & 0 & 0.61 & $0.008-1^{b}$ & 0.17976 & 0.17571 & 293 & 755 \\
\hline 1 June & Anth & 0.40 & 0.60 & 0 & 0.61 & 1 & 0.17976 & 0.17571 & 293 & 755 \\
\hline 1 June & AS & 0 & 1 & N/A & 0.61 & 1 & 0.17980 & 0.17592 & 325 & 926 \\
\hline 11 June & Biog & 0.78 & 0.22 & 0.2 & 0.61 & 1 & 0.17974 & 0.17585 & 292 & 884 \\
\hline 11 June & AS & 0 & 1 & N/A & 0.61 & 1 & 0.17976 & 0.17597 & 364 & 993 \\
\hline
\end{tabular}

a All observed inorganics are assumed to be ammonium sulphate

${ }^{\mathrm{b}} \alpha_{c}$ is assumed to start at $\alpha_{c}=0.008$ and increase exponentially to $\alpha_{c}=1$ as the amount of liquid water on the droplets increase

\section{Conclusions}

In this study with biogenically and anthropogenicallyinfluenced air, kinetics of the initial growth of cloud droplets in a $\mathrm{CCN}$ counter were measured and simulated at $S=0.35 \%$. The organic components in the anthropogenic aerosol delayed the initial growth of these particles into cloud droplets when compared with a pure ammonium sulphate (AS) aerosol $\left(D_{\text {geo }}=0.1 \mu \mathrm{m}\right)$. The best agreement between the observations and simulations was found for this set of parameters: $\kappa_{\text {org }}=0$ and an average mass accommodation coefficient of $\alpha_{c}=0.04$ for the monodisperse aerosol simulations and $\alpha_{c}=0.07$ for the polydisperse aerosol simulations. A range of $\kappa_{\text {org }}$ values are possible for the anthropogenic scenarios as changing $\kappa_{\text {org }}$ did not affect the growth rates to a great extent and thus $\kappa_{\text {org }}$ could not be constrained. A different effect was observed for fresher biogenic particles, where the organic-dominated particles exhibited similar initial growth rates as pure AS particles (monodisperse observations). The best agreement between the polydisperse observations and simulations in these cases was found for this set of parameters: $\kappa_{\text {org }}=0.2$ (with a range from 0.07 to 0.5 within the measured supersaturation uncertainty) and $\alpha_{c}=1$. Higher values of $\kappa_{\text {org }}$ are possible for the biogenic scenario but that requires decreased $\alpha_{c}$ in order to match the modelled and observed growth rates. The delay in the initial growth of the cloud droplets on anthropogenic aerosols suggest organic inhibi- tion, possibly due to the formation of an organic film that coated the aerosol/droplet. Even though the biogenic aerosol appears to be fresher, it takes up water readily perhaps because the fresh secondary organic compounds from the oxidation of forest emissions may be soluble (e.g. Engelhart et al., 2008; Hartz et al., 2005). Ruehl et al. (2008, 2009) observed droplet growth inhibition (compared to lab-generated AS) for aerosols in polluted air masses, consistent with the findings from our study.

Applying these findings in an adiabatic cloud parcel model, we find that the delay in the anthropogenic aerosol water uptake could increase (constant low $\alpha_{c}$ ) or decrease (increasing $\alpha_{c}$ with increasing liquid water on the droplets) the number of droplets, $N_{d}$, compared to either an aerosol with the same chemical composition and $\alpha_{c}=1$ or a pure AS aerosol also with $\alpha_{c}=1$. If $\alpha_{c}$ starts at a lower value and increases as more water accumulates on the droplet, the model results show a lower $N_{d}$ and liquid water content, which slightly reduces the indirect effect. The biogenic aerosol's $\kappa_{\text {org }}$ also appears to lead to slightly lower $N_{d}$ compared with the pure AS simulation. 
Acknowledgements. Thank-you to F. Froude and H. DryfhoutClark for meteorological information and to C. Green and the staff at the Centre for Atmospheric Research Experiments of Environment Canada for use of the facility and help during the study. Thanks to A. Gaudenzi, D. Halpin, S. Sharma, S. Sjostedt and D. Toom-Sauntry throughout the field campaign and to L.M. Russell for helpful discussions. The authors gratefully acknowledge the NOAA Air Resources Laboratory for the provision of the HYSPLIT transport and dispersion model website (http://www.arl.noaa.gov/ready.html) used in this publication. The authors thank CFCAS for financial support, through the CloudAerosol Feedbacks and Climate Network. Support to SOCAAR for the AMS came from CFI and OIT. R. Chang was supported by an NSERC CGS-D Scholarship. The authors thank 2 anonymous reviewers for helpful comments and suggestions.

Edited by: M. Gysel

\section{References}

Abbatt, J. P. D., Broekhuizen, K., and Kumar, P. P.: Cloud condensation nucleus activity of internally mixed ammonium sulfate/organic acid aerosol particles, Atmos. Environ., 39, 47674778, 2005.

Aiken, A. C., DeCarlo, P. F., Kroll, J. H., Worsnop, D. R., Huffman, J. A., Docherty, K. S., Ulbrich, I. M., Mohr, C., Kimmel, J. R., Sueper, D., Sun, Y., Zhang, Q., Trimborn, A., Northway, M., Ziemann, P. J., Canagaratna, M. R., Onasch, T. B., Alfarra, M. R., Prevot, A. S. H., Dommen, J., Duplissy, J., Metzger, A., Baltensperger, U., and Jimenez, J. L.: O/C and OM/OC Ratios of Primary, Secondary, and Ambient Organic Aerosols with HighResolution Time-of-Flight Aerosol Mass Spectrometry, Environ. Sci. Technol., 42, 4478-4485, 2008.

Albrecht, B. A.: Aerosols, Cloud Microphysics, and Fractional Cloudiness, Science, 245, 1227-1230, 1989.

Broekhuizen, K., Chang, R.Y.-W., Leaitch, W. R., Li, S.-M., and Abbatt, J. P. D.: Closure between measured and modeled cloud condensation nuclei (CCN) using size-resolved aerosol compositions in downtown Toronto, Atmos. Chem. Phys., 6, 2513-2524, 2006, http://www.atmos-chem-phys.net/6/2513/2006/.

Canagaratna, M. R., Jayne, J. T., Jimenez, J. L., Allan, J. D., Alfarra, M. R., Zhang, Q., Onasch, T. B., Drewnick, F., Coe, H., Middlebrook, A., Delia, A., Williams, L. R., Trimborn, A. M., Northway, M. J., DeCarlo, P. F., Kolb, C. E., Davidovits, P., and Worsnop, D. R.: Chemical and microphysical characterization of ambient aerosols with the aerodyne aerosol mass spectrometer, Mass Spectrom. Rev., 26, 185-222, 2007.

Chan, T. W., Huang, L., Leaitch, W. R., Sharma, S., Brook, J. R., Slowik, J. G., Abbatt, J. P. D., Brickell, P. C., Liggio, J., Li, S.M., and Moosmüller, H.: Determination of OM/OC ratios and specific attenuation coefficients (SAC) in ambient fine PM at a rural site in southern Ontario: implications for emission sources, particle aging, and radiative forcing, Atmos. Chem. Phys. Discuss., 9, 14315-14359, 2009,

http://www.atmos-chem-phys-discuss.net/9/14315/2009/.

Chang, R. Y.-W., Slowik, J. G., Shantz, N. C., Vlasenko, A., Liggio, J., Sjostedt, S. J., Leaitch, W. R., and Abbatt, J. P. D.: The hygroscopicity parameter $(\kappa)$ of ambient organic aerosol at a field site subject to biogenic and anthropogenic influences: Relationship to degree of aerosol oxidation, Atmos. Chem. Phys. Discuss., 9, 25323-25360, 2009,

http://www.atmos-chem-phys-discuss.net/9/25323/2009/.

Chang, R. Y. W., Liu, P. S. K., Leaitch, W. R., and Abbatt, J. P. D.: Comparison between measured and predicted $\mathrm{CCN}$ concentrations at Egbert, Ontario: Focus on the organic aerosol fraction at a semi-rural site, Atmos. Environ., 41, 8172-8182, 2007.

Chuang, P. Y., Charlson, R. J., and Seinfeld, J. H.: Kinetic limitations on droplet formation in clouds, Nature, 390, 594-596, 1997.

Chuang, P. Y.: Measurement of the timescale of hygroscopic growth for atmospheric aerosols, J. Geophys. Res.-Atmos., 108, 4282, doi:10.1029/2002JD002757, 2003.

CRC: Handbook of Chemistry and Physics, 85th ed., edited by: Lide, D. R., Chemical Rubber Company (CRC) Press, Boca Raton, Florida, 2004.

Cross, E. S., Slowik, J. G., Davidovits, P., Allan, J. D., Worsnop, D. R., Jayne, J. T., Lewis, D. K., Canagaratna, M., and Onasch, T. B.: Laboratory and ambient particle density determinations using light scattering in conjunction with aerosol mass spectrometry, Aerosol Sci. Technol., 41, 343-359, 2007.

Cruz, C. N. and Pandis, S. N.: A study of the ability of pure secondary organic aerosol to act as cloud condensation nuclei, Atmos. Environ., 31, 2205-2214, 1997.

Davidovits, P., Worsnop, D. R., Jayne, J. T., Kolb, C. E., Winkler, P., Vrtala, A., Wagner, P. E., Kulmala, M., Lehtinen, K. E. J., Vesala, T., and Mozurkewich, M.: Mass accommodation coefficient of water vapor on liquid water, Geophys. Res. Lett., 31, L22111, doi:10.1029/2004GL020835, 2004.

Drewnick, F., Hings, S. S., DeCarlo, P., Jayne, J. T., Gonin, M., Fuhrer, K., Weimer, S., Jimenez, J. L., Demerjian, K. L., Borrmann, S., and Worsnop, D. R.: A new time-of-flight aerosol mass spectrometer (TOF-AMS) - Instrument description and first field deployment, Aerosol Sci. Technol., 39, 637-658, 2005.

Duplissy, J., Gysel, M., Alfarra, M. R., Dommen, J., Metzger, A., Prevot, A. S. H., Weingartner, E., Laaksonen, A., Raatikainen, T., Good, N., Turner, S. F., McFiggans, G., and Baltensperger, U.: Cloud forming potential of secondary organic aerosol under near atmospheric conditions, Geophys. Res. Lett., 35, L03818, doi:10.1029/2007GL031075, 2008.

Engelhart, G. J., Asa-Awuku, A., Nenes, A., and Pandis, S. N.: $\mathrm{CCN}$ activity and droplet growth kinetics of fresh and aged monoterpene secondary organic aerosol, Atmos. Chem. Phys., 8, 3937-3949, 2008, http://www.atmos-chem-phys.net/8/3937/2008/.

Feingold, G. and Chuang, P. Y.: Analysis of the influence of filmforming compounds on droplet growth: Implications for cloud microphysical processes and climate, J. Atmos. Sci., 59, 20062018, 2002.

Fountoukis, C. and Nenes, A.: Continued development of a cloud droplet formation parameterization for global climate models, J. Geophys. Res.-Atmos., 110, D11212, doi:10.1029/2004JD005591, 2005.

Fountoukis, C., Nenes, A., Meskhidze, N., Bahreini, R., Conant, W. C., Jonsson, H., Murphy, S., Sorooshian, A., Varutbangkul, V., Brechtel, F., Flagan, R. C., and Seinfeld, J. H.: Aerosol-cloud drop concentration closure for clouds sampled during the International Consortium for Atmospheric Research on Transport and 
Transformation 2004 campaign, J. Geophys. Res.-Atmos., 112, D10S30, doi: 10.1029/2006JD007272, 2007.

Gunthe, S. S., King, S. M., Rose, D., Chen, Q., Roldin, P., Farmer, D. K., Jimenez, J. L., Artaxo, P., Andreae, M. O., Martin, S. T., and Pöschl, U.: Cloud condensation nuclei in pristine tropical rainforest air of Amazonia: size-resolved measurements and modeling of atmospheric aerosol composition and CCN activity, Atmos. Chem. Phys., 9, 7551-7575, 2009, http://www.atmos-chem-phys.net/9/7551/2009/.

Hartz, K. E. H., Rosenorn, T., Ferchak, S. R., Raymond, T. M., Bilde, M., Donahue, N. M., and Pandis, S. N.: Cloud condensation nuclei activation of monoterpene and sesquiterpene secondary organic aerosol, J. Geophys. Res.-Atmos., 110, D14208, doi:10.1029/2004JD005754, 2005.

Jayne, J. T., Leard, D. C., Zhang, X. F., Davidovits, P., Smith, K. A., Kolb, C. E., and Worsnop, D. R.: Development of an aerosol mass spectrometer for size and composition analysis of submicron particles, Aerosol Sci. Technol., 33, 49-70, 2000.

Jimenez, J. L., Jayne, J. T., Shi, Q., Kolb, C. E., Worsnop, D. R., Yourshaw, I., Seinfeld, J. H., Flagan, R. C., Zhang, X. F., Smith, K. A., Morris, J. W., and Davidovits, P.: Ambient aerosol sampling using the Aerodyne Aerosol Mass Spectrometer, J. Geophys. Res.-Atmos., 108, 8425, doi:10.1029/2001JD001213, 2003.

Jimenez, J. L., Canagaratna, M. R., Donahue, N. M., Prevot, A. S. H., Zhang, Q., Kroll, J. H., DeCarlo, P. F., Allan, J. D., Coe, H., Ng, N. L., Aiken, A. C., Docherty, K. S., Ulbrich, I. M., Grieshop, A. P., Robinson, A. L., Duplissy, J., Smith, J. D., Wilson, K. R., Lanz, V. A., Hueglin, C., Sun, Y. L., Tian, J., Laaksonen, A., Raatikainen, T., Rautiainen, J., Vaattovaara, P., Ehn, M., Kulmala, M., Tomlinson, J. M., Collins, D. R., Cubison, M. J., Dunlea, E. J., Huffman, J. A., Onasch, T. B., Alfarra, M. R., Williams, P. I., Bower, K., Kondo, Y., Schneider, J., Drewnick, F., Borrmann, S., Weimer, S., Demerjian, K., Salcedo, D., Cottrell, L., Griffin, R., Takami, A., Miyoshi, T., Hatakeyama, S., Shimono, A., Sun, J. Y., Zhang, Y. M., Dzepina, K., Kimmel, J. R., Sueper, D., Jayne, J. T., Herndon, S. C., Trimborn, A. M., Williams, L. R., Wood, E. C., Middlebrook, A. M., Kolb, C. E., Baltensperger, U., and Worsnop, D. R.: Evolution of organic aerosols in the atmosphere, Science, 326, 1525-1529, 2009.

Johnson, G. R., Ristovski, Z. D., D'Anna, B., and Morawska, L.: Hygroscopic behavior of partially volatilized coastal marine aerosols using the volatilization and humidification tandem differential mobility analyzer technique, J. Geophys. Res.-Atmos., 110, D20203, doi:10.1029/2004JD005657, 2005.

Jurányi, Z., Gysel, M., Duplissy, J., Weingartner, E., Tritscher, T., Dommen, J., Henning, S., Ziese, M., Kiselev, A., Stratmann, F., George, I., and Baltensperger, U.: Influence of gasto-particle partitioning on the hygroscopic and droplet activation behaviour of $\alpha$-pinene secondary organic aerosol, Phys. Chem. Chem. Phys., 11, 8091-8097, 2009.

Kanakidou, M., Seinfeld, J. H., Pandis, S. N., Barnes, I., Dentener, F. J., Facchini, M. C., Van Dingenen, R., Ervens, B., Nenes, A., Nielsen, C. J., Swietlicki, E., Putaud, J. P., Balkanski, Y., Fuzzi, S., Horth, J., Moortgat, G. K., Winterhalter, R., Myhre, C. E. L., Tsigaridis, K., Vignati, E., Stephanou, E. G., and Wilson, J.: Organic aerosol and global climate modelling: a review, Atmos. Chem. Phys., 5, 1053-1123, 2005,

http://www.atmos-chem-phys.net/5/1053/2005/.
Laaksonen, A., Vesala, T., Kulmala, M., Winkler, P. M., and Wagner, P. E.: Commentary on cloud modelling and the mass accommodation coefficient of water, Atmos. Chem. Phys., 5, 461-464, 2005 , http://www.atmos-chem-phys.net/5/461/2005/.

Leaitch, W. R., Strapp, J. W., and Isaac, G. A.: Cloud droplet nucleation and cloud scavenging of aerosol sulphate in polluted atmospheres, Tellus, 38B, 328-344, 1986.

Leaitch, W. R., Bottenheim, J. W., Biesenthal, T. A., Li, S. M., Liu, P. S. K., Asalian, K., Dryfhout-Clark, H., Hopper, F., and Brechtel, F.: A case study of gas-to-particle conversion in an eastern Canadian forest, J. Geophys. Res.-Atmos., 104, 80958111, 1999.

Liou, K. N. and Ou, S. C.: The Role of Cloud Microphysical Processes in Climate - an Assessment from a One-Dimensional Perspective, J. Geophys. Res.-Atmos., 94, 8599-8607, 1989.

Liu, P. S. K., Deng, R., Smith, K. A., Williams, L. R., Jayne, J. T., Canagaratna, M. R., Moore, K., Onasch, T. B., Worsnop, D. R., and Deshler, T.: Transmission efficiency of an aerodynamic focusing lens system: Comparison of model calculations and laboratory measurements for the Aerodyne Aerosol Mass Spectrometer, Aerosol Sci. Technol., 41, 721-733, 2007.

Marek, R., and Straub, J.: Analysis of the evaporation coefficient and the condensation coefficient of water, Int. J. Heat Mass Transf., 44, 39-53, 2001.

Medina, J., Nenes, A., Sotiropoulou, R. E. P., Cottrell, L. D., Ziemba, L. D., Beckman, P. J., and Griffin, R. J.: Cloud condensation nuclei closure during the International Consortium for Atmospheric Research on Transport and Transformation 2004 campaign: Effects of size-resolved composition, J. Geophys. Res.Atmos., 112, D10S31, doi:10.1029/2006JD007588, 2007.

Ming, Y. and Russell, L. M.: Organic aerosol effects on fog droplet spectra, J. Geophys. Res.-Atmos., 109, D10206, doi:10.1029/2003JD004427, 2004.

Mozurkewich, M.: Aerosol Growth and the Condensation Coefficient for Water - a Review, Aerosol Sci. Technol., 5, 223-236, 1986.

Petters, M. D. and Kreidenweis, S. M.: A single parameter representation of hygroscopic growth and cloud condensation nucleus activity, Atmos. Chem. Phys., 7, 1961-1971, 2007, http://www.atmos-chem-phys.net/7/1961/2007/.

Petters, M. D. and Kreidenweis, S. M.: A single parameter representation of hygroscopic growth and cloud condensation nucleus activity - Part 2: Including solubility, Atmos. Chem. Phys., 8, 6273-6279, 2008, http://www.atmos-chem-phys.net/8/6273/2008/.

Prenni, A. J., Petters, M. D., Kreidenweis, S. M., DeMott, P. J., and Ziemann, P. J.: Cloud droplet activation of secondary organic aerosol, J. Geophys. Res.-Atmos., 112, D10223, doi:10.1029/2006JD007963, 2007.

Ruehl, C. R., Chuang, P. Y., and Nenes, A.: How quickly do cloud droplets form on atmospheric particles?, Atmos. Chem. Phys., 8, 1043-1055, 2008, http://www.atmos-chem-phys.net/8/1043/2008/.

Ruehl, C. R., Chuang, P. Y., and Nenes, A.: Distinct CCN activation kinetics above the marine boundary layer along the California coast, Geophys. Res. Lett., 36, L15814, doi:10.1029/2009GL038839, 2009. 
Shantz, N. C., Leaitch, W. R., and Caffrey, P. F.: Effect of organics of low solubility on the growth rate of cloud droplets, J. Geophys. Res.-Atmos., 108, 4168-4176, 2003.

Shantz, N. C., Leaitch, W. R., Phinney, L., Mozurkewich, M., and Toom-Sauntry, D.: The effect of organic compounds on the growth rate of cloud droplets in marine and forest settings, Atmos. Chem. Phys., 8, 5869-5887, 2008, http://www.atmos-chem-phys.net/8/5869/2008/.

Shulman, M. L., Jacobson, M. C., Charlson, R. J., Synovec, R. E., and Young, T. E.: Dissolution behavior and surface tension effects of organic compounds in nucleating cloud droplets, Geophys. Res. Lett., 23, 277-280, 1996.

Slowik, J. G., Stroud, C., Bottenheim, J. W., Brickell, P. C., Chang, R. Y.-W., Liggio, J., Makar, P. A., Martin, R. V., Moran, M. D., Shantz, N. C., Sjostedt, S. J., van Donkelaar, A., Vlasenko, A., Wiebe, H. A., Xia, A. G., Zhang, J., Leaitch, W. R., and Abbatt, J. P. D.: Characterization of a large biogenic secondary organic aerosol event from eastern Canadian forests, Atmos. Chem. Phys. Discuss., 9, 18113-18158, 2009, http://www.atmos-chem-phys-discuss.net/9/18113/2009/.

Stroud, C. A., Nenes, A., Jimenez, J. L., DeCarlo, P. F., Huffman, J. A., Bruintjes, R., Nemitz, E., Delia, A. E., Toohey, D. W., Guenther, A. B., and Nandi, S.: Cloud activating properties of aerosol observed during CELTIC, J. Atmos. Sci., 64, 441-459, 2007.

Twomey, S.: Pollution and Planetary Albedo, Atmos. Environ., 8, 1251-1256, 1974.

VanReken, T. M., Ng, N. L., Flagan, R. C., and Seinfeld, J. H.: Cloud condensation nucleus activation properties of biogenic secondary organic aerosol, J. Geophys. Res.-Atmos., 110, D07206, doi:10.1029/2004JD005465, 2005.

Vesna, O., Sjogren, S., Weingartner, E., Samburova, V., Kalberer, M., Gäggeler, H. W., and Ammann, M.: Changes of fatty acid aerosol hygroscopicity induced by ozonolysis under humid conditions, Atmos. Chem. Phys., 8, 4683-4690, 2008, http://www.atmos-chem-phys.net/8/4683/2008/.
Vlasenko, A., Slowik, J. G., Bottenheim, J. W., Brickell, P. C., Chang, R. Y.-W., Macdonald, A. M., Shantz, N. C., Sjostedt, S. J., Wiebe, H. A., Leaitch, W. R., and Abbatt, J. P. D.: Measurements of VOCs by proton transfer reaction mass spectrometry at a rural Ontario site: Sources and correlation to aerosol composition, J. Geophys. Res.-Atmos., 114, D21305, doi:10.1029/2009JD012025, 2009.

Voigtländer, J., Stratmann, F., Niedermeier, D., Wex, H., and Kiselev, A.: Mass accommodation coefficient of water: A combined computational fluid dynamics and experimental data analysis, J. Geophys. Res.-Atmos., 112, D20208, doi:10.1029/2007JD008604, 2007.

Wang, J., Lee, Y.-N., Daum, P. H., Jayne, J., and Alexander, M. L.: Effects of aerosol organics on cloud condensation nucleus $(\mathrm{CCN})$ concentration and first indirect aerosol effect, Atmos. Chem. Phys., 8, 6325-6339, 2008, http://www.atmos-chem-phys.net/8/6325/2008/.

Wex, H., Petters, M. D., Carrico, C. M., Hallbauer, E., Massling, A., McMeeking, G. R., Poulain, L., Wu, Z., Kreidenweis, S. M., and Stratmann, F.: Towards closing the gap between hygroscopic growth and activation for secondary organic aerosol: Part 1 - Evidence from measurements, Atmos. Chem. Phys., 9, 3987-3997, 2009 , http://www.atmos-chem-phys.net/9/3987/2009/.

Zhang, Q., Jimenez, J. L., Canagaratna, M. R., Allan, J. D., Coe, H., Ulbrich, I., Alfarra, M. R., Takami, A., Middlebrook, A. M., Sun, Y. L., Dzepina, K., Dunlea, E., Docherty, K., DeCarlo, P. F., Salcedo, D., Onasch, T., Jayne, J. T., Miyoshi, T., Shimono, A., Hatakeyama, S., Takegawa, N., Kondo, Y., Schneider, J., Drewnick, F., Borrmann, S., Weimer, S., Demerjian, K., Williams, P., Bower, K., Bahreini, R., Cottrell, L., Griffin, R. J., Rautiainen, J., Sun, J. Y., Zhang, Y. M., and Worsnop, D. R.: Ubiquity and dominance of oxygenated species in organic aerosols in anthropogenically-influenced Northern Hemisphere midlatitudes, Geophys. Res. Lett., 34, L13801, doi:10.1029/2007GL029979, 2007. 